\title{
Genetics of autistic disorders: review and clinical implications
}

\author{
Christine M. Freitag • Wouter Staal • \\ Sabine M. Klauck · Eftichia Duketis • \\ Regina Waltes
}

Received: 30 June 2009/ Accepted: 30 October 2009/Published online: 26 November 2009

(C) The Author(s) 2009. This article is published with open access at Springerlink.com

\begin{abstract}
Twin and family studies in autistic disorders (AD) have elucidated a high heritability of AD. In this literature review, we will present an overview on molecular genetic studies in $\mathrm{AD}$ and highlight the most recent findings of an increased rate of copy number variations in AD. An extensive literature search in the PubMed database was performed to obtain English published articles on genetic findings in autism. Results of linkage, (genome wide) association and cytogenetic studies are presented, and putative aetiopathological pathways are discussed. Implications of the different genetic findings for genetic counselling and genetic testing at present will be described. The article ends with a prospectus on future directions.
\end{abstract}

Keywords Autistic disorder - Linkage ·

Whole genome association - Copy number variation . Mutation

C. M. Freitag $(\bowtie) \cdot$ E. Duketis - R. Waltes

Department of Child and Adolescent Psychiatry,

Psychosomatics, and Psychotherapy,

Johann Wolfgang Goethe-University, Deutschordenstraße 50,

60528 Frankfurt am Main, Germany

e-mail: C.Freitag@em.uni-frankfurt.de

W. Staal

Department of Child and Adolescent Psychiatry,

UMC Utrecht, Utrecht, The Netherlands

S. M. Klauck

Division of Molecular Genome Analysis, German Cancer

Research Center (DKFZ), Heidelberg, Germany

\section{Introduction}

Autistic disorders (AD) are a group of disorders characterised by the three core problem areas: qualitative impairment in social interaction and communication, and restricted repetitive and stereotyped patterns of behaviour, interests, and activities [88]. The three disorders autism, Asperger syndrome (AS) and pervasive developmental disorder-not otherwise specified (PDD-NOS) are currently conceptualised by most researchers as a continuum of the same disorder with varying degrees of severity, associated intellectual functioning and medical conditions, possibly also including the broader autism phenotype (BAP) [80]. Recent studies estimated the prevalence of $\mathrm{AD}$ to around $0.5-1 \%[5,17]$. AD are predominantly genetically determined disorders with a heritability of around 90\% [29].

Non-genetic medical conditions (phenocopies) are rare, however, they are especially relevant with regard to the prevention of AD. Retrospective case series clearly indicate maternal valproic acid use [87] during pregnancy as risk factor. The association of congenital rubella with autism has been studied in a longitudinal study on 243 children with congenital rubella of whom $7 \%$ developed typical or atypical autism [18]. With about $2 \%$, another relatively frequent medical condition in $\mathrm{AD}$ is cerebral palsy [28].

The findings of cytogenetic abnormalities and single gene disorders associated with $\mathrm{AD}$ indicate genetic heterogeneity and different modes of inheritance in individual families. For idiopathic AD, i.e. cases with unknown genetic or environmental cause, oligogenic, polygenic, and multifactorial mechanisms have additionally been proposed. Some evidence points to a different genetic model in simplex versus multiplex AD cases [93]. Previously, hypothesis free genome wide linkage approaches were 
performed to elicit relevant genetic loci. Mutation analyses and candidate gene association studies attempted to elucidate rare or common variants associated with the disorder. Owing to technical advances in CHIP based technology and cytogenetics, recent studies have focussed on hypotheses free genome wide association (GWA) and copy number variation $(\mathrm{CNV})$ studies.

In this review on molecular genetic findings in $\mathrm{AD}$, we summarise findings of a previous review article on the genetics of AD [29] and add findings from recent studies (2007-2009). For both articles, a systematic search on molecular genetic studies in AD was performed using the database PubMed and adding information from reference lists of published articles. The following key words were used: "autistic disorder", "autism spectrum disorder", "autism", "Asperger Syndrome" in combination with "genetic", "gene", "linkage", "association", "copy number variation", "genome wide", "cytogenetic", "duplication", "deletion", "translocation". Results of association studies were only reported if at least one replication of another or the same variant in the specific gene was published. For a graphical overview on the reported replicated findings, compare Fig. 1.

\section{Linkage studies}

Linkage studies aim to elicit gene loci by mapping genes in families. Linkage can be defined as the tendency for alleles close together on the same chromosome to be transmitted together, as an intact unit, through meiosis. Linkage studies are either performed as full genome screens with a dense set of genetic markers covering all chromosomes, or locally (fine-mapping) at a certain chromosomal area of interest. Linkage has been found in at least two independent studies in regions 2q21-33, 3q25-27, 3p25, 4q32, 6q14-21, 7q22, 7q31-36, 11p1213, 17q11-21 [2, 24, 29, 50, 60, 74]. A meta-analysis confirmed the region $7 \mathrm{q} 22-32$, and reported suggestive evidence for linkage to 10p12-q11.1 and 17p11.2-q12 [75]. Due to the rarity of the disorder, genome scans often were first performed in a smaller set of families and again in an enlarged set of families, containing the previously assessed families as well. This, however, did not always result in more pronounced linkage findings at previously described loci, but more often in diminished LOD scores. This might be due to different loci containing risk genes in different populations, to false positive or negative findings due to differing linkage disequilibrium patterns in different populations, towards the involvement of risk alleles of small effect, which are not detected by linkage studies, and again towards heterogeneity of AD.
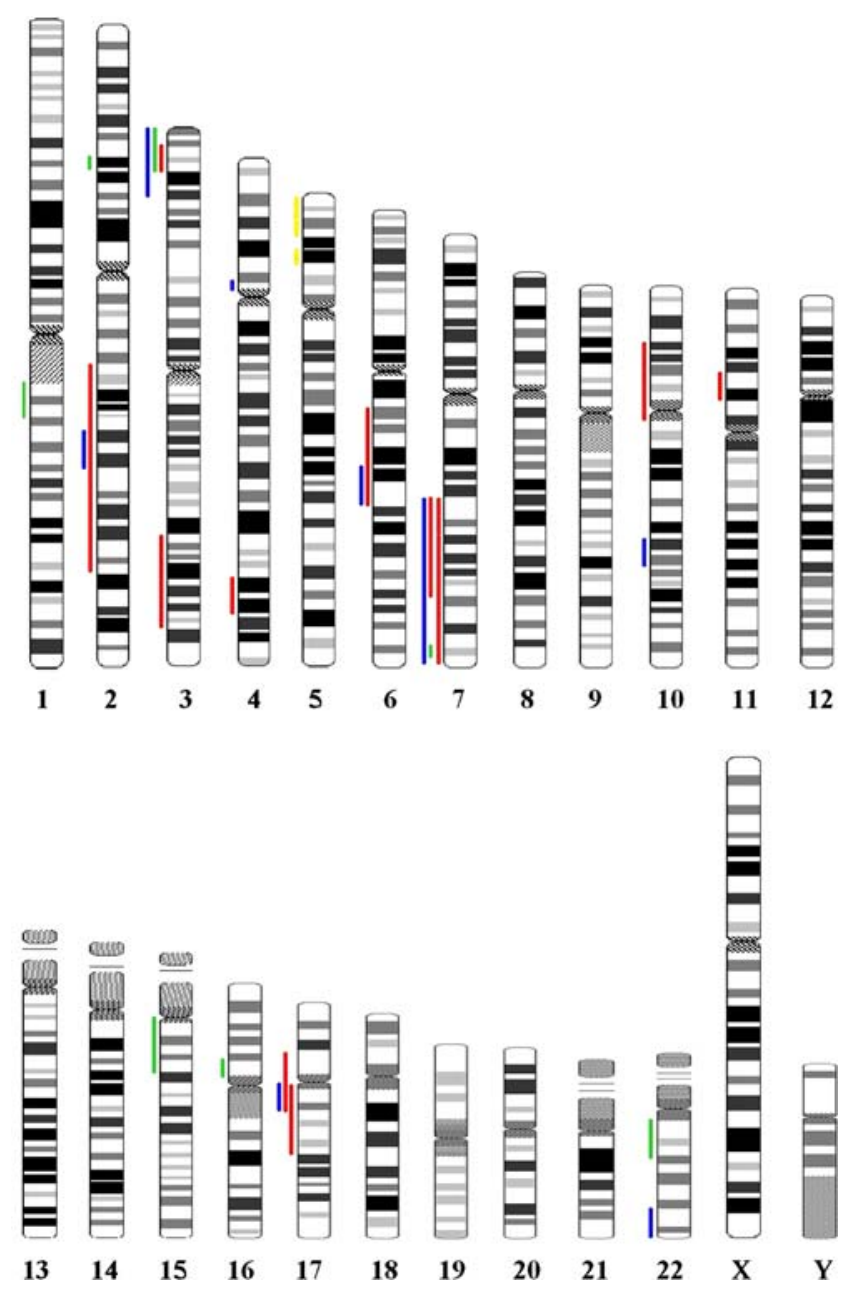

Fig. 1 Replicated findings of linkage (red bars), Genome wide association (yellow bars), copy number variation (green bars) and candidate gene (blue bars) studies as discussed in the text

\section{Single gene disorders and findings of association studies}

Co-occurrence of $\mathrm{AD}$ and single gene disorders has been observed for a long time. The most prevalent single gene disorders in $\mathrm{AD}$ are tuberous sclerosis (TSC1/TSC2; around $1 \%$ ) and fragile $X$ syndrome (around 3-5\%). More rare $(\ll 1 \%)$, but medically treatable single gene disorders are phenylketonuria (PKU) and Smith-Lemli-Opitz (SLO) syndrome caused by mutations in 7-dehydrocholesterol reductase (DHCR7) $[4,29,66]$. The rate of $\mathrm{AD}$ in these disorders also is increased, but $\mathrm{AD}$ is not observed in all individuals carrying the mutation: fragile-X-syndrome ca. $25 \%$ (males), tuberous sclerosis ca. 20\%; SLO ca. 50\%; PKU ca. $10 \%$ [1]. Mutation screening and subsequent association studies have elucidated other rare causes of (most likely) single gene disorders in individuals with AD. Additionally, several common variants in genes located in linked regions were assessed for association with $\mathrm{AD}$. In 
the following overview, only replicated association findings will be presented.

\section{Chromosome 2}

Different common variants in the mitochondrial aspartate/ glutamate carrier (SLC25A12) gene located on 2q24 were associated with AD in several studies [29, 67].

\section{Chromosome 3}

Oxytocin plays a crucial role in social cognition and behaviour [22] and the oxytocin receptor gene (OXTR) is located under the linkage peak on 3p24-26. Several single nucleotide polymorphism (SNP) alleles and haplotypes of OXTR were associated with $\mathrm{AD}[40,46,89]$.

\section{Chromosome 4}

One association study and a cytogenetic finding point towards the possible involvement of GABA-A receptor subunit genes encoded on chromosome 4p12 [29, 79]. In addition, a gene expression study observed down-regulation of several GABA-A-receptor subunits in the parietal cortex of individuals with autism [25]. No association studies were performed to date on genes at the $4 \mathrm{q} 32$ locus.

\section{Chromosome 6}

Three studies found evidence for association of different SNP genotypes or alleles in the Glutamate receptor 6 (GluR6) gene under the linkage peak on chromosome 6 [29].

\section{Chromosome 7}

Most candidate genes assessed in $\mathrm{AD}$ are located on chromosome 7q22-36, as this area is best replicated from linkage studies. Mutations or variants in the following candidate genes could not clearly be replicated as risk factors for AD [29]: FOXP2 (a gene which was mutated in a severe monogenic form of speech and language impairment in one family) [27], RELN (neuronal migration, formation of cortical layers, synaptogenesis), PTPRZ1 (highly expressed during embryogenesis), NRCAM, WNT2, and HOXAl (hindbrain development in mouse).

The RELN (Reelin) gene codes for a signalling protein that plays a crucial role in neuronal migration, formation of cortical layers and synaptogenesis. Three studies supported the involvement of a trinucleotide repeat polymorphism in the $5^{\prime} \mathrm{UTR}$ region in Reelin in $\mathrm{AD}[58,64,69]$, whereas five other, at least similarly powered, studies did not [9, 21, 44, 47, 92].

Different rare and common, possibly functional variants in $L A M B 1$ were associated with AD in two studies [10, 29, 38].
$L A M B 1$ encodes the $\beta 1$ chain of laminin, which is an important glycoprotein promoting neuronal migration and neurite outgrowth in the developing nervous system.

Different alleles of two SNPs in the Engrailed 2 (EN2)gene on chromosome $7 \mathrm{q} 36$ were associated with $\mathrm{AD}$ in several independent samples $[11,29,84,90] . E N 2$ is a homeobox transcription factor, which plays a role during the development of cerebellar and brainstem functions.

Common variants as well as rare mutations in the contactin-associated protein-like 2 (CNTNAP2), a member of the neurexin superfamily involved in cell-adhesion and neuronal migration $[2,3,6]$ also increased the risk for $\mathrm{AD}$ in several independent samples. Gene-expression analyses in the developing human brain identified CNTNAP2 as enriched in circuits important for language development.

The gene encoding the pleiotropic MET receptor tyrosine kinase plays a role in brain development and gastrointestinal repair. As some individuals with AD suffer from gastrointestinal symptoms (GIS), this gene was specifically assessed in individuals with $\mathrm{AD}$ and GIS. A functional promotor variant, several other SNP genotypes or alleles as well as rare mutations were associated with $\mathrm{AD}$ in several independent samples, predominantly in individuals with GIS [14, 16, 71]. In a post-mortem brain protein-expression analysis, AD individuals showed lower levels of the MET protein compared to controls [15].

\section{Chromosome 10}

PTEN (phosphatase and tensin homologue, located on 10q23.3) is a tumour suppressor gene that acts as a negative regulator in the PI3-kinase (PI3K) pathway. Heterozygous PTEN mutations were identified in a subset of individuals with autism, macrocephaly and/or developmental delay $[13,35,78]$, thus rendering affected individuals PTENhaploinsufficient.

\section{Chromosome 15}

Several variants of genes on 15q11-13 were assessed as risk factors, as cytogenetic abnormalities of this region are frequently observed in $\mathrm{AD}$ (see below). In candidate gene association studies to date, inconclusive findings were reported with regard to $A T P 10 C, U B E 3 A$ and the gammaaminobutyric acid (GABA) receptor genes located on $15 \mathrm{q}$ [29].

\section{Chromosome 17}

Due to findings of platelet hyperserotonemia in children with autism and their first-degree relatives, common variants in the Serotonin-transporter gene (SLC6A4) were assessed by several studies [29]. A recent meta-analysis, 
however, did not report an effect of 5-HTTLPR and STin2 alleles on $\mathrm{AD}$ risk [37].

\section{Chromosome 22}

Several case reports indicated 22q13.3 deletions and duplications as risk factors for AD. Therefore, SHANK3, the gene encoding a synaptic scaffolding protein, was assessed for mutations and common variants possibly associated with AD. Several studies observed rare mutations in individuals with $\mathrm{AD}$, occurring most often de novo, but also inherited from (unaffected) parents. Similar to reports of mutations of X-chromosomal genes (see below), SHANK3 mutations might cause a monogenic form of non-verbal or severely speech delayed AD [23, $30,56]$. The frequency of SHANK3 mutations was estimated to $0.5-1 \%$ in $\mathrm{AD}$ individuals. Common variants were not detected as risk factors [73]. A recent study, however, also has reported $S H A N K 3$ deletions in healthy individuals [31].

\section{X-chromosome}

Despite rare positive linkage findings for loci on the $\mathrm{X}$ chromosome, several variants in genes on the X-chromosome were assessed for association with $\mathrm{AD}$, as the sex distribution in $\mathrm{AD}$ is markedly skewed (male:female $=4: 1$ ). Two neuroligin genes on Xq13 and Xp22 were screened for mutations in several studies. Neuroligins are essential components of synaptogenesis. Despite the findings of several non-conservative mutations in single families in NLGN3 and NLGN4 these could not be replicated in larger samples of individuals with AD [29]. Similarly, two mutations identified in the ribosomal protein gene RPL10 on Xq28 were not replicated in a subsequent study [32, 43].

MeCP2-mutations are risk factors for Rett-Syndrome, which by some authors is regarded as an AD, but clearly differs phenotypically from $\mathrm{AD}$ by deterioration of motor abilities and very low IQ. In addition, in males with mental retardation and progressive spasticity, duplications of the MECP2 region were repeatedly observed [48]. In AD samples in contrast, no association of MeCP2 variants was found [29].

\section{Y-chromosome}

There are only a few studies, which have investigated variants of Y chromosomal genes in autism. A recent study reported nominal association with a SNP variant in NLGN4Y [63] in contrast to previous findings [42, 91]. Thus, an influence of genes on the $\mathrm{Y}$ chromosome has not been established to date.

\section{Genome wide association studies}

The above reported candidate gene association studies are based on specific hypotheses. Results in one sample often were not replicated in subsequent samples, possibly indicating false positive reports. Other causes might be heterogeneity across populations, bias due to technical artefacts, population stratification or environmental modifiers. False negative reports, especially in light of genes of small effect, hamper further understanding of genetic mechanisms in autism. Similar to linkage studies, genome wide association (GWA) studies are considered hypothesis-free studies. Performing a GWA study in a sufficiently large sample and replicating the most significant SNPs in an independent sample with sufficient power is currently considered as a design avoiding the report of false positive findings [70]. However, GWA studies to date did not replicate any of the previous linkage or association findings, most likely due to the same reasons as the non-replication of hypotheses based association studies. In addition, the "common disease-common variant" genetic model underlying GWA studies might not hold true for the majority of AS cases [51]. GWA studies done on currently available samples and with the currently available SNP assays cannot detect risk alleles with low minor allele frequency or rare variants which might be relevant in the aetiology of AD [53]. To date, three GWA studies were performed in $\mathrm{AD}[49,83$, 85]. Common genetic variants on 5 p14.1 and 5 p15 were replicated in two independent samples, respectively, each carrying a small increased risk (OR 1.2) or protective effect (OR 0.6) [83, 85].

At 5p14.1 segments with a high degree of evolutionary conservation can be found, suggesting potential regulatory function. Genes $\mathrm{CDH} 9$ and $\mathrm{CDH} 10$ are near the two replicated SNPs [83]. These genes encode cadherins, which are a group of proteins that are involved in calciumdependent cell-cell junctions in the nervous system, thereby shaping the physical structure and functional connectivity of the brain. The one replicated SNP at 5p15 is located near TAS2R1, a gene encoding a bitter taste receptor, and the semaphorin $5 \mathrm{~A}$ gene (SEMA5A) implicated in axonal guidance. SEMA5A was downregulated in lymphoblastoid cell lines as well as occipital lobe cortex in $\mathrm{AD}[85]$.

\section{Chromosomal abnormalities}

For a long time suspected causes of heterogeneity in AD are chromosomal abnormalities which can be observed by standard karyotyping. Numerous case reports of chromosomal abnormalities on almost each single chromosome in $\mathrm{AD}$ do exist [82], however, epidemiological data are 
missing to date. Shortcomings of most cytogenetic studies are the lack of standardised assessment methods for $\mathrm{AD}$, the inclusion of subjects with autistic features but no clear $\mathrm{AD}$ diagnosis, and the lack of standardised assessment of cognitive and adaptive functioning. Recent studies estimated a rate of 3-5\% of cytogenetic abnormalities in AD [59]. Some studies aimed to elicit candidate genes or candidate gene regions by a detailed analysis of the boundaries of the cytogenetic abnormalities found in AD [82].

With a rate of approximately $1 \%$, the most prevalent cytogenetic abnormalities are observed on chromosome 15q11-13 [20, 29], in most cases maternally, but also paternally inherited duplications. Further relatively frequent findings are deletions of chromosome $2 q 37$, chromosome $7 q 31$ and deletions or duplications of chromosome $22 q 13$. In addition, Klinefelter Syndrome (XXY) as well as duplications of the Williams-Beuren-Syndrome region 7q11.23 and deletions of $22 q 11$ (Velo-cardio-facial Syndrome) are associated with increased autistic traits $[8,77,81]$.

Due to autistic traits in several chromosomal aneuploidies, a cytogenetic evaluation has to be recommended in all subjects with $\mathrm{AD}$. Some studies reported higher rates of deletions, duplications or translocations in AD individuals with mental retardation, abnormal EEG patterns or seizures, muscular hypotonia, severe motor and gait problems, or dysmorphic features [41], however, chromosomal anomalies are also observed in individuals without dysmorphic features [82]. The finding of a chromosomal anomaly as a likely cause of AD has strong implications for genetic counselling and in some cases, like Klinefelter or Velo-cardio-facial Syndrome, also for the treatment of other medical conditions associated with the respective syndrome.

\section{Submicroscopic copy number variations}

Due to technological advances, it is now possible to also assess small cytogenetic abnormalities not detected by standard karyotyping [34]. Until recently, it was thought that only $0.1 \%$ base pair changes accounted for major genetic variation between individuals. With the advance of micro-array-based comparative genomic hybridization (array-CGH), this view has been challenged by studies that showed that the genomes of unrelated healthy individuals vary significantly with respect to the number of copies an individual has of each DNA segment [39, 62]. A copy number variation $(\mathrm{CNV})$ is currently defined as a DNA segment longer than $1 \mathrm{~kb}$, with a variable copy number compared to a reference genome [26]. A CNV can be a deletion, insertion, duplication or a complex multi-site variant. It can be inherited or may arise de novo on a paternally or maternally inherited chromosome. To be pathogenic, a CNV must affect a gene in a molecular pathway important in the development or maintenance of the human body. CNVs might change the transcription rate of a gene product by increased or decreased transcription, in case of deletions, they may unmask recessive mutations, or they might change the coding sequence of a gene.

Recent publications show that some CNVs are observed more frequently in $\mathrm{AD}$ patients compared to control subjects $[12,31,45,52,55,61,86]$. Similar to the cytogenetic findings obtained by standard karyotyping, most CNVs represent rare, unique events rather than representing recurrent deletions or duplications. Replicated CNVs from genome wide studies, which were observed more frequently in $\mathrm{AD}$ compared to control individuals, are located on the following chromosomes: 1q21, 2p16.3 (NRXN1), 3p25-26 (CNTN4), 7q36.2 (DPP6), 15q11-13 (UBE3A, OR4M2, OR4N4); 16p11.2 (MAPK3, MAZ, DOC2A, SEZ6L2, HIRIP3, IL6); 22q11.2. Some of these CNV were observed also more frequently in individuals with mental retardation or schizophrenia than in controls. ASD specific CNVs were not exclusively observed in AD individuals with specific dysmorphic features or mental retardation but were also present in high-functioning patients with autism with only minor dysmorphology [76].

\section{Summary on genetic mechanisms and possible functional pathways involved in $\mathrm{AD}$}

Molecular genetic studies in AD have come a long way from the early linkage studies, which aimed at describing a few loci and subsequently finding one or a few genes of major effect relevant for all cases of AD. It has now become clear, that $\mathrm{AD}$ are heterogeneous disorders, caused by several rare-most likely-monogenetic disorders (as fragile $\mathrm{X}$ syndrome, mutations in TSC1/TSC2, LAMB1, CNTNAP2, PTEN, DHCR7, SHANK3, NLGN3/4, or RPL10). In addition, "contiguous gene syndromes" are likely causes of $\mathrm{AD}$, as the overall rate of CNVs and large chromosomal deletions, duplications, and translocations is increased in individuals with $\mathrm{AD}$ compared to controls.

Common variants, on the other hand, may shape the phenotype or eventually may lead to the disorder by interacting with rare mutations or CNVs. A mechanism like this has been shown for PTEN haploinsufficient individuals. The serotonin-transporter gene SLC6A4 has been discussed as both an AD susceptibility gene and a second-site modifier in AD [7, 36]. A study in PTEN haploinsufficient mice [57] demonstrated that the phenotypes of these mice were modified in an additive fashion by SLC6A4 haploinsufficiency. In addition, the role of PTEN in the maintenance of genomic stability $[65,72]$ makes it likely that PTEN haploinsufficiency may increase the probability of a 
secondary modifying event, such as a copy number variation in a chromosomal region relevant to $\mathrm{AD}$. Common variants also might increase the risk for autistic traits in the general population as well as for less severe autistic disorders as Asperger Syndrome or PDD-NOS.

From results of current genetic findings in $\mathrm{AD}$, it is likely that mutations or common variants in genes coding for gene products involved in (1) cell-cell interaction and synaptic function, including development of dendritic spines, (2) neuronal migration and growth, or (3) excitatory and inhibitory neurotransmission are causes of AD. The pathway influencing cell-cell interaction and synaptic function includes NRXNs, NLNGs, CNTN3/4, CNTNAP2, and SHANK3. In addition, the FMR protein, which is missing in fragile $\mathrm{X}$ syndrome, modulates dendritic spine formation and synaptic plasticity by inhibiting mGluR1/5 mediated dendritic protein synthesis [33]. Neuronal migration and growth are influenced by gene products of $L A M B 1, E N 2$ or the MET receptor tyrosine kinase gene. The mTor/PI3-kinase (PI3K) pathway involves PTEN, $T S C 1 / 2$, and several other genes, which were observed in CNVs in individuals with AD [19]. It strongly influences (neuronal) cell growth. Gene products influencing the regulation of excitatory and inhibitory neurotransmission are GABA and glutamate receptors. In addition, dysbalance of excitatory and inhibitory neurotransmission was also observed in fragile $\mathrm{X}$ syndrome. Clearly, this list of possibly involved pathways is not exhaustive, and other mechanisms or pathways may emerge as results of further studies will be published.

\section{Implications for genetic counselling}

Genetic counselling for $\mathrm{AD}$ is challenging, as phenotype and genetic mechanisms are complex. There is a strong need to carefully assess the children and their family, and to exclude all known medical causes of the disorder. The aim of genetic counselling is to provide information to parents and children, and to estimate the recurrence risk of the disorder. Genetic counselling further is concerned with providing psychologically oriented counselling to help individuals to adapt and adjust to the impact and implications of the disorder in the family. With regard to $\mathrm{AD}$, families as a rule wish to know the recurrence risk of the disorder. From the results of family studies, a sibling recurrence risk of around 5\% (2-8\%) can be estimated for "idiopathic" AD not caused by any of the currently known mechanisms [68]. If a known genetic cause of the disorder is established, however, a very different recurrence risk might be present in the individual family. For dominant single gene disorders with full penetrance, like TSC1/2mutations, a sibling recurrence risk of $50 \%$ is present, if one of the parents carries the disease-causing variant, i.e. if the variant is not a de-novo mutation. In case of recessive single gene disorders, like Smith-Lemli-Opitz syndrome, the sibling recurrence risk is $25 \%$. If a child suffers from fragile $\mathrm{X}$ syndrome, the recurrence risk in a brother is up to $50 \%$, and a sister will become a carrier in up to $50 \%$ or might be mildly affected. On the other hand, in the presence of cytogenetic abnormalities like a chromosome 15q11-13 duplication or duplicated inversion, the recurrence risk can be similar to the population prevalence, as most duplications and inversions arise de-novo during meiosis. The same is true for CNVs. However, they also can be inherited, which will result in an entirely different recurrence risk.

The limited clinical validity of genetic testing for autism and the related ethical concerns have been delineated in detail [54]. It seems of particular relevance to keep in mind the complex genetics and uncertainty principle as well as the right of the individual and the family not to participate in genetic testing. Despite contrasting information to patients, no genetic test does exist to date, by which an $\mathrm{AD}$ can be diagnosed. It remains a diagnosis based on behavioural observation.

\section{Future directions}

Due to technical advances, sequencing of the genome will be available and feasible in the near future. Similar to results of genome-wide CNV and association studies, the detection of new mutations, rare and common variants in cases as well as controls will make it difficult to prove the relevance of the findings for $\mathrm{AD}$ in general as well as for the affected individual specifically. Researchers are faced with genetic heterogeneity, reduced penetrance, unmasking of recessive alleles, "second hit" mechanisms, pleiotropy, epigenetic mechanisms, and possible environmental mediators. It therefore is of crucial relevance to include on the one hand more differentiated phenotypic measures, on the other hand functional aspects on the cellular and molecular level as well as biological network analysis approaches to focus on the most relevant findings. This approach will need large and thoroughly diagnosed samples with $\mathrm{AD}$. In parallel, knowledge about population wide variation at the genomic level in comparison with phenotypic expression of AD symptoms will add information towards involved functional pathways. The final goal anticipated is the development of therapeutic targets for drug treatments. The development of a molecular genetic test kit to assist in $\mathrm{AD}$ diagnosis might also be achieved. At the current stage of research, however, a genetic test does not seem feasible nor ethical due to the heterogeneity of the disorder, the lack of population-based 
studies on the genetics of $\mathrm{AD}$ and the lack of sensitivity and specificity analyses in comparison to other psychiatric or neurological disorders in childhood.

\section{Conclusions}

Despite the high-heritability estimates for $\mathrm{AD}$, no major gene has been observed to be relevant for the majority of $\mathrm{AD}$ diagnoses. In contrast, rare mutations of larger effect and a few common variants of small effect in several different genes, which are also involved in different cellular pathways, seem to be causal for many cases of AD. From a statistical point of view therefore, large $\mathrm{AD}$ and control samples are necessary, to prove the causality of specific rare mutations (including $\mathrm{CNVs}$ ) or variants of small effect as risk factors for AD. As the disorder shows a high-phenotypic variability and additional genetic heterogeneity, it is of crucial importance to (1) define clear phenotypes especially with regard to the broader spectrum of $\mathrm{AD}$ and to the differential diagnosis of other pervasive developmental disorders like Rett syndrome, and (2) to perform a detailed cytogenetic analysis in every individual with $\mathrm{AD}$ and additional testing for fragile $\mathrm{X}$ syndrome in individuals with $\mathrm{AD}$ and low intelligence/mental retardation in clinical and research settings. It also might be feasible in the near future, to employ kits assessing the most prevalent cytogenetic findings in individuals with AD. In addition, samples with mental retardation or other psychiatric disorders, like schizophrenia, should be compared to elicit the most specific risk factors for $\mathrm{AD}$. New technologies, such as more sophisticated chip based arrays as well as large scale sequencing will lead to new results which need to be integrated into meaningful biological models.

Open Access This article is distributed under the terms of the Creative Commons Attribution Noncommercial License which permits any noncommercial use, distribution, and reproduction in any medium, provided the original author(s) and source are credited.

\section{References}

1. Abrahams BS, Geschwind DH (2008) Advances in autism genetics: on the threshold of a new neurobiology. Nat Rev Genet 9:341-355

2. Alarcon M, Abrahams BS, Stone JL, Duvall JA, Perederiy JV, Bomar JM, Sebat J, Wigler M, Martin CL, Ledbetter DH, Nelson SF, Cantor RM, Geschwind DH (2008) Linkage, association, and gene-expression analyses identify CNTNAP2 as an autism-susceptibility gene. Am J Hum Genet 82:150-159

3. Arking DE, Cutler DJ, Brune CW, Teslovich TM, West K, Ikeda M, Rea A, Guy M, Lin S, Cook EH, Chakravarti A (2008) A common genetic variant in the neurexin superfamily member CNTNAP2 increases familial risk of autism. Am J Hum Genet 82:160-164
4. Baieli S, Pavone L, Meli C, Fiumara A, Coleman M (2003) Autism and phenylketonuria. J Autism Dev Disord 33:201-204

5. Baird G, Simonoff E, Pickles A, Chandler S, Loucas T, Meldrum D, Charman T (2006) Prevalence of disorders of the autism spectrum in a population cohort of children in South Thames: the Special Needs and Autism Project (SNAP). Lancet 368:210-215

6. Bakkaloglu B, O'Roak BJ, Louvi A, Gupta AR, Abelson JF, Morgan TM, Chawarska K, Klin A, Ercan-Sencicek AG, Stillman AA, Tanriover G, Abrahams BS, Duvall JA, Robbins EM, Geschwind DH, Biederer T, Gunel M, Lifton RP, State MW (2008) Molecular cytogenetic analysis and resequencing of contactin associated protein-like 2 in autism spectrum disorders. Am J Hum Genet 82:165-173

7. Bartlett CW, Gharani N, Millonig JH, Brzustowicz LM (2005) Three autism candidate genes: a synthesis of human genetic analysis with other disciplines. Int J Dev Neurosci 23:221-234

8. Berg JS, Brunetti-Pierri N, Peters SU, Kang SH, Fong CT, Salamone J, Freedenberg D, Hannig VL, Prock LA, Miller DT, Raffalli P, Harris DJ, Erickson RP, Cunniff C, Clark GD, Blazo MA, Peiffer DA, Gunderson KL, Sahoo T, Patel A, Lupski JR, Beaudet AL, Cheung SW (2007) Speech delay and autism spectrum behaviors are frequently associated with duplication of the $7 \mathrm{q} 11.23$ Williams-Beuren syndrome region. Genet Med 9:427-441

9. Bonora E, Beyer KS, Lamb JA, Parr JR, Klauck SM, Benner A, Paolucci M, Abbott A, Ragoussis I, Poustka A, Bailey AJ, Monaco AP (2003) Analysis of reelin as a candidate gene for autism. Mol Psychiatry 8:885-892

10. Bonora E, Lamb JA, Barnby G, Sykes N, Moberly T, Beyer KS, Klauck SM, Poustka F, Bacchelli E, Blasi F, Maestrini E, Battaglia A, Haracopos D, Pedersen L, Isager T, Eriksen G, Viskum B, Sorensen EU, Brondum-Nielsen K, Cotterill R, Engeland H, Jonge M, Kemner C, Steggehuis K, Scherpenisse M, Rutter M, Bolton PF, Parr JR, Poustka A, Bailey AJ, Monaco AP (2005) Mutation screening and association analysis of six candidate genes for autism on chromosome 7q. Eur J Hum Genet 13:198207

11. Brune CW, Korvatska E, Allen-Brady K, Cook EH Jr, Dawson G, Devlin B, Estes A, Hennelly M, Hyman SL, McMahon WM, Munson J, Rodier PM, Schellenberg GD, Stodgell CJ, Coon H (2008) Heterogeneous association between engrailed-2 and autism in the CPEA network. Am J Med Genet B Neuropsychiatr Genet 147B:187-193

12. Bucan M, Abrahams BS, Wang K, Glessner JT, Herman EI, Sonnenblick LI, Alvarez Retuerto AI, Imielinski M, Hadley D, Bradfield JP, Kim C, Gidaya NB, Lindquist I, Hutman T, Sigman M, Kustanovich V, Lajonchere CM, Singleton A, Kim J, Wassink TH, McMahon WM, Owley T, Sweeney JA, Coon H, Nurnberger JI, Li M, Cantor RM, Minshew NJ, Sutcliffe JS, Cook EH, Dawson G, Buxbaum JD, Grant SF, Schellenberg GD, Geschwind DH, Hakonarson H (2009) Genome-wide analyses of exonic copy number variants in a family-based study point to novel autism susceptibility genes. PLoS Genet 5:e1000536

13. Butler MG, Dasouki MJ, Zhou XP, Talebizadeh Z, Brown M, Takahashi TN, Miles JH, Wang CH, Stratton R, Pilarski R, Eng C (2005) Subset of individuals with autism spectrum disorders and extreme macrocephaly associated with germline PTEN tumour suppressor gene mutations. J Med Genet 42:318-321

14. Campbell DB, Buie TM, Winter H, Bauman M, Sutcliffe JS, Perrin JM, Levitt P (2009) Distinct genetic risk based on association of MET in families with co-occurring autism and gastrointestinal conditions. Pediatrics 123:1018-1024

15. Campbell DB, D'Oronzio R, Garbett K, Ebert PJ, Mirnics K, Levitt P, Persico AM (2007) Disruption of cerebral cortex MET signaling in autism spectrum disorder. Ann Neurol 62:243-250

16. Campbell DB, Sutcliffe JS, Ebert PJ, Militerni R, Bravaccio C, Trillo S, Elia M, Schneider C, Melmed R, Sacco R, Persico AM, 
Levitt P (2006) A genetic variant that disrupts MET transcription is associated with autism. Proc Natl Acad Sci USA 103:1683416839

17. Chakrabarti S, Fombonne E (2005) Pervasive developmental disorders in preschool children: confirmation of high prevalence. Am J Psychiatry 162:1133-1141

18. Chess S, Fernandez P, Korn S (1978) Behavioral consequences of congenital rubella. J Pediatr 93:699-703

19. Cusco I, Medrano A, Gener B, Vilardell M, Gallastegui F, Villa O, Gonzalez E, Rodriguez-Santiago B, Vilella E, Del CM, PerezJurado LA (2009) Autism-specific copy number variants further implicate the phosphatidylinositol signaling pathway and the glutamatergic synapse in the etiology of the disorder. Hum Mol Genet 18:1795-1804

20. Depienne C, Moreno-De-Luca D, Heron D, Bouteiller D, Gennetier A, Delorme R, Chaste P, Siffroi JP, Chantot-Bastaraud S, Benyahia B, Trouillard O, Nygren G, Kopp S, Johansson M, Rastam M, Burglen L, Leguern E, Verloes A, Leboyer M, Brice A, Gillberg C, Betancur C (2009) Screening for genomic rearrangements and methylation abnormalities of the 15q11-q13 region in autism spectrum disorders. Biol Psychiatr

21. Devlin B, Bennett P, Dawson G, Figlewicz DA, Grigorenko EL, McMahon W, Minshew N, Pauls D, Smith M, Spence MA, Rodier PM, Stodgell C, Schellenberg GD (2004) Alleles of a reelin CGG repeat do not convey liability to autism in a sample from the CPEA network. Am J Med Genet B Neuropsychiatr Genet 126:46-50

22. Donaldson ZR, Young LJ (2008) Oxytocin, vasopressin, and the neurogenetics of sociality. Science 322:900-904

23. Durand CM, Betancur C, Boeckers TM, Bockmann J, Chaste P, Fauchereau F, Nygren G, Rastam M, Gillberg IC, Anckarsater H, Sponheim E, Goubran-Botros H, Delorme R, Chabane N, Mouren-Simeoni MC, de Mas P, Bieth E, Roge B, Heron D, Burglen L, Gillberg C, Leboyer M, Bourgeron T (2007) Mutations in the gene encoding the synaptic scaffolding protein SHANK3 are associated with autism spectrum disorders. Nat Genet 39:25-27

24. Duvall JA, Lu A, Cantor RM, Todd RD, Constantino JN, Geschwind DH (2007) A quantitative trait locus analysis of social responsiveness in multiplex autism families. Am J Psychiatry 164:656-662

25. Fatemi SH, Reutiman TJ, Folsom TD, Thuras PD (2009) $\mathrm{GABA}(\mathrm{A})$ receptor downregulation in brains of subjects with autism. J Autism Dev Disord 39:223-230

26. Feuk L, Carson AR, Scherer SW (2006) Structural variation in the human genome. Nat Rev Genet 7:85-97

27. Fisher SE, Vargha-Khadem F, Watkins KE, Monaco AP, Pembrey ME (1998) Localisation of a gene implicated in a severe speech and language disorder. Nat Genet 18:168-170

28. Fombonne E (2003) The prevalence of autism. JAMA 289:87-89

29. Freitag CM (2007) The genetics of autistic disorders and its clinical relevance: a review of the literature. Mol Psychiatry $12: 2-22$

30. Gauthier J, Spiegelman D, Piton A, Lafreniere RG, Laurent S, StOnge J, Lapointe L, Hamdan FF, Cossette P, Mottron L, Fombonne E, Joober R, Marineau C, Drapeau P, Rouleau GA (2009) Novel de novo SHANK3 mutation in autistic patients. Am J Med Genet B Neuropsychiatr Genet 150B:421-424

31. Glessner JT, Wang K, Cai G, Korvatska O, Kim CE, Wood S, Zhang $\mathrm{H}$, Estes A, Brune $\mathrm{CW}$, Bradfield JP, Imielinski M, Frackelton EC, Reichert J, Crawford EL, Munson J, Sleiman PM, Chiavacci R, Annaiah K, Thomas K, Hou C, Glaberson W, Flory J, Otieno F, Garris M, Soorya L, Klei L, Piven J, Meyer KJ, Anagnostou E, Sakurai T, Game RM, Rudd DS, Zurawiecki D, McDougle CJ, Davis LK, Miller J, Posey DJ, Michaels S, Kolevzon A, Silverman JM, Bernier R, Levy SE, Schultz RT, Dawson G, Owley T, McMahon WM, Wassink TH, Sweeney JA,
Nurnberger JI, Coon H, Sutcliffe JS, Minshew NJ, Grant SF, Bucan M, Cook EH, Buxbaum JD, Devlin B, Schellenberg GD, Hakonarson H (2009) Autism genome-wide copy number variation reveals ubiquitin and neuronal genes. Nature

32. Gong X, Delorme R, Fauchereau F, Durand CM, Chaste P, Betancur C, Goubran-Botros H, Nygren G, Anckarsater H, Rastam M, Gillberg IC, Kopp S, Mouren-Simeoni MC, Gillberg C, Leboyer M, Bourgeron T (2009) An investigation of ribosomal protein $\mathrm{L} 10$ gene in autism spectrum disorders. BMC Med Genet 10:7

33. Hagerman RJ, Berry-Kravis E, Kaufmann WE, Ono MY, Tartaglia N, Lachiewicz A, Kronk R, Delahunty C, Hessl D, Visootsak J, Picker J, Gane L, Tranfaglia M (2009) Advances in the treatment of fragile X syndrome. Pediatrics 123:378-390

34. Henrichsen CN, Chaignat E, Reymond A (2009) Copy number variants, diseases and gene expression. Hum Mol Genet 18:R1$\mathrm{R} 8$

35. Herman GE, Butter E, Enrile B, Pastore M, Prior TW, Sommer A (2007) Increasing knowledge of PTEN germline mutations: two additional patients with autism and macrocephaly. Am J Med Genet A 143:589-593

36. Hessl D, Tassone F, Cordeiro L, Koldewyn K, McCormick C, Green C, Wegelin J, Yuhas J, Hagerman RJ (2008) Brief report: aggression and stereotypic behavior in males with fragile $\mathrm{X}$ syndrome-moderating secondary genes in a "single gene" disorder. J Autism Dev Disord 38:184-189

37. Huang CH, Santangelo SL (2008) Autism and serotonin transporter gene polymorphisms: a systematic review and meta-analysis. Am J Med Genet B Neuropsychiatr Genet 147B:903-913

38. Hutcheson HB, Olson LM, Bradford Y, Folstein SE, Santangelo SL, Sutcliffe JS, Haines JL (2004) Examination of NRCAM, LRRN3, KIAA0716, and LAMB1 as autism candidate genes. BMC Med Genet 5:12

39. Iafrate AJ, Feuk L, Rivera MN, Listewnik ML, Donahoe PK, Qi Y, Scherer SW, Lee C (2004) Detection of large-scale variation in the human genome. Nat Genet 36:949-951

40. Jacob S, Brune CW, Carter CS, Leventhal BL, Lord C, Cook EH $\mathrm{Jr}$ (2007) Association of the oxytocin receptor gene (OXTR) in Caucasian children and adolescents with autism. Neurosci Lett 417:6-9

41. Jacquemont ML, Sanlaville D, Redon R, Raoul O, Cormier-Daire V, Lyonnet S, Amiel J, Le Merrer M, Heron D, de Blois MC, Prieur M, Vekemans M, Carter NP, Munnich A, Colleaux L, Philippe A (2006) Array-based comparative genomic hybridisation identifies high frequency of cryptic chromosomal rearrangements in patients with syndromic autism spectrum disorders. J Med Genet 43:843-849

42. Jamain S, Quach H, Quintana-Murci L, Betancur C, Philippe A, Gillberg C, Sponheim E, Skjeldal OH, Fellous M, Leboyer M, Bourgeron T (2002) Y chromosome haplogroups in autistic subjects. Mol Psychiatry 7:217-219

43. Klauck SM, Felder B, Kolb-Kokocinski A, Schuster C, Chiocchetti A, Schupp I, Wellenreuther R, Schmotzer G, Poustka F, Breitenbach-Koller L, Poustka A (2006) Mutations in the ribosomal protein gene RPL10 suggest a novel modulating disease mechanism for autism. Mol Psychiatry 11:1073-1084

44. Krebs MO, Betancur C, Leroy S, Bourdel MC, Gillberg C, Leboyer M (2002) Absence of association between a polymorphic GGC repeat in the 5' untranslated region of the reelin gene and autism. Mol Psychiatry 7:801-804

45. Kumar RA, Karamohamed S, Sudi J, Conrad DF, Brune C, Badner JA, Gilliam TC, Nowak NJ, Cook EH Jr, Dobyns WB, Christian SL (2008) Recurrent 16p11.2 microdeletions in autism. Hum Mol Genet 17:628-638

46. Lerer E, Levi S, Salomon S, Darvasi A, Yirmiya N, Ebstein RP (2007) Association between the oxytocin receptor (OXTR) gene 
and autism: relationship to Vineland Adaptive Behavior Scales and cognition. Mol Psychiatry

47. Li J, Nguyen L, Gleason C, Lotspeich L, Spiker D, Risch N, Myers RM (2004) Lack of evidence for an association between WNT2 and RELN polymorphisms and autism. Am J Med Genet B Neuropsychiatr Genet 126:51-57

48. Lugtenberg D, Kleefstra T, Oudakker AR, Nillesen WM, Yntema HG, Tzschach A, Raynaud M, Rating D, Journel H, Chelly J, Goizet C, Lacombe D, Pedespan JM, Echenne B, Tariverdian G, O'Rourke D, King MD, Green A, van KM, Van EH, Gecz J, Hamel BC, van BH, de Brouwer AP (2009) Structural variation in Xq28: MECP2 duplications in $1 \%$ of patients with unexplained XLMR and in $2 \%$ of male patients with severe encephalopathy. Eur J Hum Genet 17:444-453

49. Ma D, Salyakina D, Jaworski JM, Konidari I, Whitehead PL, Andersen AN, Hoffman JD, Slifer SH, Hedges DJ, Cukier HN, Griswold AJ, McCauley JL, Beecham GW, Wright HH, Abramson RK, Martin ER, Hussman JP, Gilbert JR, Cuccaro ML, Haines JL, Pericak-Vance MA (2009) A genome-wide association study of autism reveals a common novel risk locus at 5p14.1. Ann Hum Genet 73:263-273

50. Ma DQ, Cuccaro ML, Jaworski JM, Haynes CS, Stephan DA, Parod J, Abramson RK, Wright HH, Gilbert JR, Haines JL, Pericak-Vance MA (2007) Dissecting the locus heterogeneity of autism: significant linkage to chromosome 12q14. Mol Psychiatry $12: 376-384$

51. Manolio TA, Collins FS, Cox NJ, Goldstein DB, Hindorff LA, Hunter DJ, McCarthy MI, Ramos EM, Cardon LR, Chakravarti A, Cho JH, Guttmacher AE, Kong A, Kruglyak L, Mardis E, Rotimi CN, Slatkin M, Valle D, Whittemore AS, Boehnke M, Clark AG, Eichler EE, Gibson G, Haines JL, Mackay TF, McCarroll SA, Visscher PM (2009) Finding the missing heritability of complex diseases. Nature 461:747-753

52. Marshall CR, Noor A, Vincent JB, Lionel AC, Feuk L, Skaug J, Shago M, Moessner R, Pinto D, Ren Y, Thiruvahindrapduram B, Fiebig A, Schreiber S, Friedman J, Ketelaars CE, Vos YJ, Ficicioglu C, Kirkpatrick S, Nicolson R, Sloman L, Summers A, Gibbons CA, Teebi A, Chitayat D, Weksberg R, Thompson A, Vardy C, Crosbie V, Luscombe S, Baatjes R, Zwaigenbaum L, Roberts W, Fernandez B, Szatmari P, Scherer SW (2008) Structural variation of chromosomes in autism spectrum disorder. Am J Hum Genet 82:477-488

53. McCarthy MI, Abecasis GR, Cardon LR, Goldstein DB, Little J, Ioannidis JP, Hirschhorn JN (2008) Genome-wide association studies for complex traits: consensus, uncertainty and challenges. Nat Rev Genet 9:356-369

54. McMahon WM, Baty BJ, Botkin J (2006) Genetic counseling and ethical issues for autism. Am J Med Genet C Semin Med Genet 142:52-57

55. Mefford HC, Sharp AJ, Baker C, Itsara A, Jiang Z, Buysse K, Huang S, Maloney VK, Crolla JA, Baralle D, Collins A, Mercer C, Norga K, de RT, Devriendt K, Bongers EM, de LN, Reardon W, Gimelli S, Bena F, Hennekam RC, Male A, Gaunt L, ClaytonSmith J, Simonic I, Park SM, Mehta SG, Nik-Zainal S, Woods CG, Firth HV, Parkin G, Fichera M, Reitano S, Lo GM, Li KE, Casuga I, Broomer A, Conrad B, Schwerzmann M, Raber L, Gallati S, Striano P, Coppola A, Tolmie JL, Tobias ES, Lilley C, Armengol L, Spysschaert Y, Verloo P, De CA, Goossens L, Mortier G, Speleman F, van BE, Nelen MR, Hochstenbach R, Poot M, Gallagher L, Gill M, McClellan J, King MC, Regan R, Skinner C, Stevenson RE, Antonarakis SE, Chen C, Estivill X, Menten B, Gimelli G, Gribble S, Schwartz S, Sutcliffe JS, Walsh T, Knight SJ, Sebat J, Romano C, Schwartz CE, Veltman JA, de Vries BB, Vermeesch JR, Barber JC, Willatt L, Tassabehji M, Eichler EE (2008) Recurrent rearrangements of chromosome 1q21.1 and variable pediatric phenotypes. $\mathrm{N}$ Engl J Med 359:1685-1699

56. Moessner R, Marshall CR, Sutcliffe JS, Skaug J, Pinto D, Vincent J, Zwaigenbaum L, Fernandez B, Roberts W, Szatmari P, Scherer SW (2007) Contribution of SHANK3 mutations to autism spectrum disorder. Am J Hum Genet 81:1289-1297

57. Page DT, Kuti OJ, Prestia C, Sur M (2009) Haploinsufficiency for Pten and Serotonin transporter cooperatively influences brain size and social behavior. Proc Natl Acad Sci USA 106:1989-1994

58. Persico AM, D’Agruma L, Maiorano N, Totaro A, Militerni R, Bravaccio C, Wassink TH, Schneider C, Melmed R, Trillo S, Montecchi F, Palermo M, Pascucci T, Puglisi-Allegra S, Reichelt KL, Conciatori M, Marino R, Quattrocchi CC, Baldi A, Zelante L, Gasparini P, Keller F (2001) Reelin gene alleles and haplotypes as a factor predisposing to autistic disorder. Mol Psychiatry 6:150-159

59. Reddy KS (2005) Cytogenetic abnormalities and fragile- $X$ syndrome in Autism Spectrum Disorder. BMC Med Genet 6:3-19

60. Schellenberg GD, Dawson G, Sung YJ, Estes A, Munson J, Rosenthal E, Rothstein J, Flodman P, Smith M, Coon H, Leong L, Yu CE, Stodgell C, Rodier PM, Spence MA, Minshew N, McMahon WM, Wijsman EM (2006) Evidence for multiple loci from a genome scan of autism kindreds. Mol Psychiatry 11:10491060, 979

61. Sebat J, Lakshmi B, Malhotra D, Troge J, Lese-Martin C, Walsh T, Yamrom B, Yoon S, Krasnitz A, Kendall J, Leotta A, Pai D, Zhang R, Lee YH, Hicks J, Spence SJ, Lee AT, Puura K, Lehtimaki T, Ledbetter D, Gregersen PK, Bregman J, Sutcliffe JS, Jobanputra V, Chung W, Warburton D, King MC, Skuse D, Geschwind DH, Gilliam TC, Ye K, Wigler M (2007) Strong association of de novo copy number mutations with autism. Science 316:445-449

62. Sebat J, Lakshmi B, Troge J, Alexander J, Young J, Lundin P, Maner S, Massa H, Walker M, Chi M, Navin N, Lucito R, Healy J, Hicks J, Ye K, Reiner A, Gilliam TC, Trask B, Patterson N, Zetterberg A, Wigler M (2004) Large-scale copy number polymorphism in the human genome. Science 305:525-528

63. Serajee FJ, Huq AH (2009) Association of Y chromosome haplotypes with autism. J Child Neurol

64. Serajee FJ, Zhong H, Mahbubul Huq AH (2006) Association of Reelin gene polymorphisms with autism. Genomics 87:75-83

65. Shen WH, Balajee AS, Wang J, Wu H, Eng C, Pandolfi PP, Yin Y (2007) Essential role for nuclear PTEN in maintaining chromosomal integrity. Cell 128:157-170

66. Sikora DM, Pettit-Kekel K, Penfield J, Merkens LS, Steiner RD (2006) The near universal presence of autism spectrum disorders in children with Smith-Lemli-Opitz syndrome. Am J Med Genet A 140:1511-1518

67. Silverman JM, Buxbaum JD, Ramoz N, Schmeidler J, Reichenberg A, Hollander E, Angelo G, Smith CJ, Kryzak LA (2008) Autism-related routines and rituals associated with a mitochondrial aspartate/glutamate carrier SLC25A12 polymorphism. Am J Med Genet B Neuropsychiatr Genet 147:408-410

68. Simonoff E (1998) Genetic counseling in autism and pervasive developmental disorders. J Autism Dev Disord 28:447-456

69. Skaar DA, Shao Y, Haines JL, Stenger JE, Jaworski J, Martin ER, DeLong GR, Moore JH, McCauley JL, Sutcliffe JS, Ashley-Koch AE, Cuccaro ML, Folstein SE, Gilbert JR, Pericak-Vance MA (2005) Analysis of the RELN gene as a genetic risk factor for autism. Mol Psychiatry 10:563-571

70. Skol AD, Scott LJ, Abecasis GR, Boehnke M (2006) Joint analysis is more efficient than replication-based analysis for twostage genome-wide association studies. Nat Genet 38:209-213

71. Sousa I, Clark TG, Toma C, Kobayashi K, Choma M, Holt R, Sykes NH, Lamb JA, Bailey AJ, Battaglia A, Maestrini E, 
Monaco AP (2009) MET and autism susceptibility: family and case-control studies. Eur J Hum Genet 17:749-758

72. Stiles BL (2009) Phosphatase and tensin homologue deleted on chromosome 10: extending its PTENtacles. Int J Biochem Cell Biol 41:757-761

73. Sykes NH, Toma C, Wilson N, Volpi EV, Sousa I, Pagnamenta AT, Tancredi R, Battaglia A, Maestrini E, Bailey AJ, Monaco AP (2009) Copy number variation and association analysis of SHANK3 as a candidate gene for autism in the IMGSAC collection. Eur J Hum Genet

74. Szatmari P, Paterson AD, Zwaigenbaum L, Roberts W, Brian J, Liu XQ, Vincent JB, Skaug JL, Thompson AP, Senman L, Feuk L, Qian C, Bryson SE, Jones MB, Marshall CR, Scherer SW, Vieland VJ, Bartlett C, Mangin LV, Goedken R, Segre A, Pericak-Vance MA, Cuccaro ML, Gilbert JR, Wright HH, Abramson RK, Betancur C, Bourgeron T, Gillberg C, Leboyer M, Buxbaum JD, Davis KL, Hollander E, Silverman JM, Hallmayer J, Lotspeich L, Sutcliffe JS, Haines JL, Folstein SE, Piven J, Wassink TH, Sheffield V, Geschwind DH, Bucan M, Brown WT, Cantor RM, Constantino JN, Gilliam TC, Herbert M, Lajonchere C, Ledbetter DH, Lese-Martin C, Miller J, Nelson S, Samango-Sprouse CA, Spence S, State M, Tanzi RE, Coon H, Dawson G, Devlin B, Estes A, Flodman P, Klei L, McMahon WM, Minshew N, Munson J, Korvatska E, Rodier PM, Schellenberg GD, Smith M, Spence MA, Stodgell C, Tepper PG, Wijsman EM, Yu CE, Roge B, Mantoulan C, Wittemeyer K, Poustka A, Felder B, Klauck SM, Schuster C, Poustka F, Bolte S, Feineis-Matthews S, Herbrecht E, Schmotzer G, Tsiantis J, Papanikolaou K, Maestrini E, Bacchelli E, Blasi F, Carone S, Toma C, van Engeland H, de Jonge M, Kemner C, Koop F, Langemeijer M, Hijimans C, Staal WG, Baird G, Bolton PF, Rutter ML, Weisblatt E, Green J, Aldred C, Wilkinson JA, Pickles A, Le Couteur A, Berney T, McConachie H, Bailey AJ, Francis K, Honeyman G, Hutchinson A, Parr JR, Wallace S, Monaco AP, Barnby G, Kobayashi K, Lamb JA, Sousa I, Sykes N, Cook EH, Guter SJ, Leventhal BL, Salt J, Lord C, Corsello C, Hus V, Weeks DE, Volkmar F, Tauber M, Fombonne E, Shih A (2007) Mapping autism risk loci using genetic linkage and chromosomal rearrangements. Nat Genet 39:319-328

75. Trikalinos TA, Karvouni A, Zintzaras E, Ylisaukko-Oja T, Peltonen L, Jarvela I, Ioannidis JP (2006) A heterogeneity-based genome search meta-analysis for autism-spectrum disorders. Mol Psychiatry 11:29-36

76. van der Zwaag B, Franke L, Poot M, Hochstenbach R, Spierenburg HA, Vorstman JA, van DE, De Jonge MV, Verbeek NE, Brilstra EH, van't SR, Ophoff RA, van Es MA, Blauw HM, Veldink JH, Buizer-Voskamp JE, Beemer FA, van den Berg LH, Wijmenga C, van Amstel HK, van EH, Burbach JP, Staal WG (2009) Gene-network analysis identifies susceptibility genes related to glycobiology in autism. PLoS ONE 4:e5324

77. van Rijn S, Swaab H, Aleman A, Kahn RS (2008) Social behavior and autism traits in a sex chromosomal disorder: Klinefelter (47XXY) syndrome. J Autism Dev Disord 38:16341641

78. Varga EA, Pastore M, Prior T, Herman GE, McBride KL (2009) The prevalence of PTEN mutations in a clinical pediatric cohort with autism spectrum disorders, developmental delay, and macrocephaly. Genet Med 11:111-117

79. Vincent JB, Horike SI, Choufani S, Paterson AD, Roberts W, Szatmari P, Weksberg R, Fernandez B, Scherer SW (2006) An inversion inv(4)(p12-p15.3) in autistic siblings implicates the $4 p$ GABA receptor gene cluster. J Med Genet 43:429-434

80. Volkmar FR, Lord C, Bailey A, Schultz RT, Klin A (2004) Autism and pervasive developmental disorders. J Child Psychol Psychiatry 45:135-170
81. Vorstman JA, Morcus ME, Duijff SN, Klaassen PW, Heinemande Boer JA, Beemer FA, Swaab H, Kahn RS, van Engeland H (2006) The 22q11.2 deletion in children: high rate of autistic disorders and early onset of psychotic symptoms. J Am Acad Child Adolesc Psychiatry 45:1104-1113

82. Vorstman JA, Staal WG, van Daalen E, van Engeland H, Hochstenbach PF, Franke L (2006) Identification of novel autism candidate regions through analysis of reported cytogenetic abnormalities associated with autism. Mol Psychiatry 11:1, 18-1, 28

83. Wang K, Zhang H, Ma D, Bucan M, Glessner JT, Abrahams BS, Salyakina D, Imielinski M, Bradfield JP, Sleiman PM, Kim CE, Hou C, Frackelton E, Chiavacci R, Takahashi N, Sakurai T, Rappaport E, Lajonchere CM, Munson J, Estes A, Korvatska O, Piven J, Sonnenblick LI, Alvarez Retuerto AI, Herman EI, Dong H, Hutman T, Sigman M, Ozonoff S, Klin A, Owley T, Sweeney JA, Brune CW, Cantor RM, Bernier R, Gilbert JR, Cuccaro ML, McMahon WM, Miller J, State MW, Wassink TH, Coon H, Levy SE, Schultz RT, Nurnberger JI, Haines JL, Sutcliffe JS, Cook EH, Minshew NJ, Buxbaum JD, Dawson G, Grant SF, Geschwind DH, Pericak-Vance MA, Schellenberg GD, Hakonarson H (2009) Common genetic variants on 5p14.1 associate with autism spectrum disorders. Nature

84. Wang L, Jia M, Yue W, Tang F, Qu M, Ruan Y, Lu T, Zhang H, Yan H, Liu J, Guo Y, Zhang J, Yang X, Zhang D (2008) Association of the ENGRAILED 2 (EN2) gene with autism in Chinese Han population. Am J Med Genet B Neuropsychiatr Genet 147B:434-438

85. Weiss LA, Arking DE, Daly MJ, Chakravarti A (2009) A genome-wide linkage and association scan reveals novel loci for autism. Nature 461:802-808

86. Weiss LA, Shen Y, Korn JM, Arking DE, Miller DT, Fossdal R, Saemundsen E, Stefansson H, Ferreira MA, Green T, Platt OS, Ruderfer DM, Walsh CA, Altshuler D, Chakravarti A, Tanzi RE, Stefansson K, Santangelo SL, Gusella JF, Sklar P, Wu BL, Daly MJ (2008) Association between microdeletion and microduplication at 16p11.2 and autism. N Engl J Med 358:667-675

87. Williams G, King J, Cunningham M, Stephan M, Kerr B, Hersh JH (2001) Fetal valproate syndrome and autism: additional evidence of an association. Dev Med Child Neurol 43:202-206

88. WorldHealth Organisation (1992) The ICD-10 classification of mental and behavioural disorders. Clinical descriptions and diagnostic guidelines. World Health Organisation, Geneva

89. Wu S, Jia M, Ruan Y, Liu J, Guo Y, Shuang M, Gong X, Zhang Y, Yang X, Zhang D (2005) Positive association of the oxytocin receptor gene (OXTR) with autism in the Chinese Han population. Biol Psychiatry 58:74-77

90. Yang P, Lung FW, Jong YJ, Hsieh HY, Liang CL, Juo SH (2008) Association of the homeobox transcription factor gene ENGRAILED 2 with autistic disorder in Chinese children. Neuropsychobiology 57:3-8

91. Ylisaukko-Oja T, Rehnstrom K, Auranen M, Vanhala R, Alen R, Kempas E, Ellonen P, Turunen JA, Makkonen I, Riikonen R, Nieminen-von Wendt T, von Wendt L, Peltonen L, Jarvela I (2005) Analysis of four neuroligin genes as candidates for autism. Eur J Hum Genet

92. Zhang H, Liu X, Zhang C, Mundo E, Macciardi F, Grayson DR, Guidotti AR, Holden JJ (2002) Reelin gene alleles and susceptibility to autism spectrum disorders. Mol Psychiatry 7:10121017

93. Zhao X, Leotta A, Kustanovich V, Lajonchere C, Geschwind DH, Law K, Law P, Qiu S, Lord C, Sebat J, Ye K, Wigler M (2007) A unified genetic theory for sporadic and inherited autism. Proc Natl Acad Sci USA 104:12831-12836 